DOI 10.15290/cnisk.2021.01.10.04

EWA MAJ

https://orcid.org/0000-0002-7295-1759

Uniwersytet Marii Curie-Skłodowskiej w Lublinie

\title{
Katolicka, katolicko-narodowa i narodowa prasa dla kobiet w Polsce międzywojennej: cechy czasopiśmiennictwa światopoglądowego ${ }^{1}$
}

\begin{abstract}
Streszczenie
Celem artykułu jest rekonstrukcja strategii komunikacyjnej przygotowanej dla czasopiśmiennictwa światopoglądowego adresowanego do kobiet w Polsce międzywojennej. Powstanie i rozwój tego typu prasy były zdeterminowane przez decyzje podejmowane przez Kościół katolicki, który zmierzał do pogłębienia wpływu na środowiska kobiece. Pod pojęciem prasy katolickiej, katolicko-narodowej i narodowej znalazły się periodyki, w których deklarowano więź z katolicyzmem, przetwarzano informacje o sytuacji Kościoła katolickiego, prezentowano wiedzę o doktrynie religijnej, a także pogłębiano tożsamość i jedność narodową. Prasotwórcza funkcję pełniły społeczne zrzeszenia katoliczek, w tym stowarzyszenia majace aspiracje polityczne. Głosiły idee komplementarnego ujmowania spraw konfesyjnych i etnicznych. Korzystały $z$ archetypu kobiecości wkomponowanego w wizję Polki katoliczki i Matki-Polki.

Słowa kluczowe: Polska międzywojenna, prasa, kobiety, katolicyzm, naród, ideał Polki katoliczki i Matki-Polki

\footnotetext{
Publikacja przygotowana/finansowana w ramach programu Ministra Nauki i Szkolnictwa Wyższego pod nazwa DIALOG w latach 2019-2021. Jest wynikiem udziału w projekcie badawczym pt. „Ośrodek badań historii kobiet”, nr 0016/DLG/2019/10.
} 


\title{
THE SECOND POLISH REPUBLIC'S CATHOLIC, NATIONAL CATHOLIC AND NATIONAL PRESS FOR WOMEN: FEATURES OF WORLDVIEW PERIODICALS
}

\begin{abstract}
The aim of the article was to reconstruct the means of communication in Interwar Poland's worldview press for women. The origins and development of such periodicals was determined by the decisions made by the Catholic Church, which wanted to gain more influence on Polish women. Catholic, National Catholic and National press declared their affiliation with the Catholic faith, informed about the state of the Church, presented the doctrine and deepen the National identity and unity. These periodicals were created by the Catholic women's associations, including those with political aspirations. To achieve their goals, they were using archetypes of Polish Mother and Polish women as Catholics.
\end{abstract}

Keywords: Interwar Poland, press, women, Catholicism, nation, Polish Mother, Polish Catholic women

\section{Wprowadzenie}

Tematyka poświęcona prasotwórczej działalności kobiet nieustannie inspiruje badania naukowe. Powstała już literatura przedmiotu zawierająca efekty eksploracji poszczególnych tytułów prasowych, inicjatyw wydawniczych, a także aparatu nadawczego wraz z poznawaniem postaci wydawczyń, redaktorek i publicystek ${ }^{2}$. Eksploracja czasopiśmiennictwa ukierunkowanego na czytelniczki oznaczała docenienie rangi wydawnictw periodycznych, które były tworzone głównie przez kobiety i dla kobiet ${ }^{3}$. Stosunkowo wielu monograficznych ujęć doczekały się tygodniki i miesięczniki adresowane do kobiet, cieszace się popularnością w warunkach politycznych przed odzyskaniem przez Polskę niepodległości oraz w okresie międzywojnia. Szczególnym zainteresowaniem badawczym cieszyły się

\footnotetext{
2 Małgorzata Dajnowicz, Adam Miodowski (red.), Polityka i politycy $w$ prasie XX $i$ XXI wieku. Polityka w prasie kobiecej, (Białystok: Wydawnictwo Uniwersytetu w Białymstoku, 2019). 3 Joanna Dufrat, „Prasa politycznych organizacji kobiecych w Polsce w latach 1917-1939”, w: Małgorzata Dajnowicz, Adam Miodowski (red.), Polityka i politycy w prasie XX $i$ XXI wieku. Prasa organizacji politycznych, (Białystok: Wydawnictwo HUMANICA, 2017), 31-48; Ewa Maj, Dziennikarki prasy dla kobiet $w$ Polsce 1918-1939. Portret zbiorowy na podstawie publicystycznego samopisu, (Lublin: Wydawnictwo Uniwersytetu Marii Curie-Skłodowskiej, 2020).
} 
czasopisma ogólnotematyczne, jak „Bluszcz” czy „Kobieta Współczesna”, „Moja Przyjaciółka”. Jednakże pogłębionego poznania w dalszym ciąu wymaga czasopiśmiennictwo zdeterminowane ideologia narodową i światopoglądem katolickim ${ }^{5}$. Nadal widoczna jest luka w pozyskiwaniu wiedzy o dziejach wydawnictw periodycznych, które deklarowały więź $z$ wierzeniem religijnym, podbudowaną wartościami narodowymi o cechach ekskluzywizmu politycznego.

Cele i zakres badawczy poniższego tekstu obejmuja rekonstrukcję wybranych komponentów historii segmentu prasowego dla kobiet, uwarunkowanego odwołaniem do aksjologii konfesyjno-etnicznej. Badania prowadzily do dywersyfikacji terminologii, w tym definiowania prasy katolickiej, katolicko-narodowej i narodowej w ujęciu szerszym - dla zwolenniczek czy sympatyczek ekskluzywizmu narodowego podbudowanego doktryną religijną, oraz w ujęciu węższym - zredukowanym do aparatu nadawczego Narodowej Demokracji (ND), Chrześcijańskiej Demokracji (ChD) oraz środowisk Akcji Katolickiej. W każdym wypadku zwracano uwage na cechy prasy adresowanej do kobiet.

Badanie walidacyjne czasopiśmiennictwa światopoglądowego służyło ustaleniu tego, w jakim stopniu narzędzie pomiaru stałej/zmiennej w jednym periodyku było zrozumiałe i użyteczne w innym periodyku, a ponadto czy przynosiło dane na temat obecności katoliczek w zorganizowanym życiu społecznym Polski. Zastosowana metodologia pozwoliła na uzyskanie efektów eksploracji periodyków w okolicznościach, gdy porównywa się obiekty (czasopisma) tożsame aksjologicznie i różne pod względem stosunku do wybranych składników społecznych ról kobiet. Dawała możność rozwią-

\footnotetext{
4 Jolanta Chwastyk-Kowalczyk, „Bluszcz” w latach 1918-1939. Tematyka społeczna oraz problemy kultury i literatury, (Kielce: Wydawnictwo Akademii Świętokrzyskiej, 2003); eadem, "Agitacja obywatelska przed- i powyborcza 1928 roku na łamach "Kobiety Współczesnej«", Czasopismo Naukowe Instytutu Studiów Kobiecych, $\mathrm{nr}$ 1, 2019, 105-137; Feliks Fikus, „Wielkie wydawnictwo prasowe w małym mieście: dwie "Przyjaciółki»", Kwartalnik Historii Prasy Polskiej, nr 1, 1979, 79-93; Joanna Grabowska, „Moja Przyjaciółka”. Ilustrowany dwutygodnik kobiecy 1934-1939, (Żnin: Muzeum Ziemi Pałuckiej w Żninie, 1997); Katarzyna Wodniak, „Moja Przyjaciółka” 1934-1939. Przebój prasowy żnińskich Zakładów Wydawniczych Alfreda Krzyckiego, (Żnin: Wydawnictwo Dominika Księskiego Wulkan, Bydgoszcz: Wydawnictwo Uniwersytetu Kazimierza Wielkiego, 2020).

5 Ewa Maj, „Wzorzec kobiety w prasie dla katoliczek w Polsce międzywojennej: przypadek periodyku "Kuźniczanka" (1931-1936)", Czasopismo Naukowe Instytutu Studiów Kobiecych, nr 1, 2020, 113-139; Iwonna Michalska, "Rodzinne obowiąki kobiety w świetle katolickiego periodyku "Gazeta dla Kobiet" z lat 1918-1938”, Lubelski Rocznik Pedagogiczny, nr 1, 2020, $27-41$.
} 
zania tytułowego problemu w toku zwracania uwagi na uniwersalne składniki matrycy czasopiśmienniczej zawierającej odniesienia do periodyczności, zawartości gatunkowej (w genologicznym ujęciu artykułów prasowych, felietonów, reportaży), dostępności i zasięgu.

\section{Uwarunkowania}

Segmentacja rynku prasowego dla katoliczek stanowiła pochodną uwarunkowań społecznych w pierwszej połowie XX w. Była efektem pogłębiania przestrzeni komunikacyjnej wspieranej przez Kościół katolicki. Poczawszy od encykliki papieża Leona XIII Etsi nos z $1882 \mathrm{r}$. w kolejnych dokumentach papieskich pojawiały się kwestie „dobrej prasy”, która miała stanowić odpowiedź na poczucie zalewu publikacji szerzacych immoralizm, materializm, hedonizm. Chodziło o uchronienie społeczeństwa przed wydawnictwami książkowymi i prasowymi, a następnie także radiowymi i filmowymi, mającymi wpływ na procesy laicyzacji życia społecznego. Cytowano fragmenty wypowiedzi Piusa X skierowanej do dziennikarzy: „Na próżno będziecie budować kościoły, odprawiać misje, zakładać szkoły, wykonywać dobre uczynki wszelkiego rodzaju; wszystkie wasze zabiegi będą daremne, jeżeli nie będziecie umieli używać broni odpornej i zaczepnej, jaką jest szczerze katolicka prasa"6. Umasowione wydawnictwa periodyczne tworzyły przestrzeń dyskursu publicznego, w którym podejmowano kwestie istotne dla społeczeństwa. Papieskie wypowiedzi były dowodem docenienia obecności czasopiśmiennictwa w sferze bezpośredniego oddziaływania na postawy i zachowania katolików. Inspirowały do zajmowania się wydawaniem periodyków przez osoby duchowne i świeckie, cieszące się autorytetem. Ponadto zachęcały do podejmowania pogłębionej pracy analitycznej nad charakterem i cechami prasy traktowanej jako „duchowa wielkorzadczyni” ${ }^{7}$.

\footnotetext{
6 Cyt. za: „Od Redakcji”, Teologia Praktyczna, nr 1, 1939, 4; Jan Chrapek, Jerzy Góral, „Zarys ważniejszych wynalazków z dziedziny masowego komunikowania oraz wypowiedzi Kościoła na temat środków społecznego przekazu”, w: Jan Chrapek (red.), Kościół a środki społecznego przekazu. Praca zbiorowa, (Warszawa: Pallotinum, 1990), 197-200.

Franciszek Radziwiłł, „Znaczenie i potrzeby prasy katolickiej”, w: Jan Pawelski (red.), Pamiętnik Zjazdu Skargowskiego w Krakowie w dniach 25 i 26 września 1912 r., (Kraków: Drukarnia Eugeniusza i Kazimierza Koziańskich, 1912), 38.
} 
Powyższe określenie pochodziło $z$ referatu wygłoszonego przez Franciszka Radziwiłła podczas zjazdu ku czci Piotra Skargi. Zjazd odbył się 25 i 26 września 1912 r. w Krakowie z udziałem wybitnych postaci ze świata polityki i nauki oraz biskupa krakowskiego Adama Sapiehy. Referaty m.in. wygłosili przedstawiciele środowisk arystokratycznych, oprócz Radziwiłła, mającego tytuł ksiażęcy, mówcami byli hrabiowie Stanisław Tarnowski i Stanisław Henryk Badeni, posłowie do galicyjskiego Sejmu Krajowego we Lwowie. Ponadto wypowiadał się działacz ChD Karol Roleksa, a ze środowiska naukowego byli: historyk Bronisław Dembiński i ekonomista Leopold Caro, zwolennik solidaryzmu katolickiego, a także ksiądz Kazimierz Zimmermann, teoretyk myśli chrześcijańsko-społecznej. Organizacją spotkania i publikacja zbioru referatów zajął się jezuita Jan Pawelski, mający doświadczenie czasopiśmiennicze przy redagowaniu dwóch krakowskich miesięczników: „Przeglądu Uniwersalnego” i „Przeglądu Powszechnego”. W tym gronie Franciszek Radziwiłł wypowiadał się o potędze prasy, w której odzwierciedlały się myśli hegemoniczne dla poszczególnych epok historycznych. Swoją wypowiedź utrzymał w porządku dychotomicznego oglądu świata jako miejsca walk dobra, upostaciowionego w katolicyzmie, i zła, znajdującego się w wielu wytworach ludzkich pozbawionych odwołania do wartości religijnych i patriotycznych. Na ziemiach polskich widział obecność periodyków, które toczyła „gangrena nowoczesna", identyfikowana $z$ postawą antyreligijna i antyklerykalna, a tym samym wymierzona $\mathrm{w}$ interesy narodu polskiego. Zalecał dla obrony polskości wspieranie mediów, ustalając trzy zasady działania obowiazkowe dla katolików. Po pierwsze, katolikowi nie wolno było tolerować prasy wrogiej religii i Kościołowi. Po drugie, nakazywał obowiazkowe prenumerowanie i czytanie prasy katolickiej. Po trzecie, domagał się ilościowego i jakościowego pomnożenia czasopiśmiennictwa katolickiego ${ }^{8}$. Nawiązaniem do wypowiedzi F. Radziwiłła były słowa biskupa Adama Sapiehy, który zalecał mobilizowanie Polaków do czynnego uczestnictwa w rozwijaniu czasopiśmiennictwa światopoglądowego ${ }^{9}$.

\footnotetext{
8 Pisał: „nie ścierpmy, by w naszym domu znajdowała się gazeta bez wyraźnego charakteru katolickiego; wypędźmy ją tak, jak wilka z owczarni”, Franciszek Radziwiłł, Znaczenie i potrzeby prasy katolickiej, 45.

9 Adam Sapieha, „Mowa zamykająca wiec”, w: Jan Pawelski (red.), Pamiętnik Zjazdu, 188.
} 
Bezpośrednim następstwem podejścia hierarchów kościelnych i świeckich autorytetów było kreowanie systemu prasowego dla katolików na ziemiach polskich. Podzbiorem systemu było czasopiśmiennictwo ukierunkowane na kobiety. Twórcami i kierownikami tego typu periodyków byli głównie duchowni, którzy w niektórych sytuacjach przekazywali pismo w ręce wydawczyń i redaktorek. Wśród pań kierujacych redakcjami przed 1914 r. m.in. były: Aleksandra Borkowska i Cecylia Plater-Zyberk, kierujące pismem dwutygodniowym „Kronika Rodzinna”, a także Katarzyna Płatek, redaktorka odpowiedzialna miesięcznika „Niewiasta Polska”, mającego motto „Za Wiarę i Ojczyznę"10. Od 1911 r. w Krośnie, potem w Krakowie ukazywała sie „Niewiasta Katolicka”. Pismo redagowała Aniela Kroczakowa, wydawczynią była Amelia Starowieyska, która w 1919 r. objęła funkcję redaktora dzięki poparciu udzielonemu przez kanclerza kapituły krakowskiej księdza Karola Nikiela ${ }^{11}$. Starowieyska uczestniczyła w procesie wzmacniania prasowej komunikacji społecznej poprzez wydawnictwa seryjne, jak „Biblioteczka Domowa”. W latach 1908-1914 wydawała serię broszur poświęconą głównie problemom macierzyństwa, wychowania domowego, opieki nad dziećmi, ale też część uwagi skupiała na zagadnieniach walki $z$ alkoholizmem na ziemiach polskich. Oprócz funkcji perswazyjnej wypełniała wymogi pracy informacyjnej, publikujacc dekret papieża Piusa X o zasadach pobożnego życia. Jej działalność służyła upowszechnianiu „dobrej lektury” i wzmożeniu czytelnictwa kobiet.

Wśród innych inicjatyw wydawniczych na uwagę zasługiwały prasotwórcze działania stowarzyszeń katoliczek. Spośród nich można wskazać przypadki czterech różnych periodyków, stanowiących dowód znacznej dyferencjacji form czasopiśmienniczych. Przypadek pierwszy to wychodzace od 1897 r. pismo „Przyjaciel

\footnotetext{
10 Wśród najstarszych czasopism ukierunkowanych na katoliczki znalazła się „Kronika Rodzinna”, pismo dwutygodniowe, mające początek w 1867 r., ukazujące się w Warszawie w 1. 1867-1914, red. i wyd. Aleksandra Borkowska. Kolejnymi redaktorami byli: Cecylia Plater-Zyberk, ks. Hipolit Skimborowicz, od 1905 ks. Marceli Godlewski, od 1911 Adam Ludwik Szymański. Z kolei miesięcznik „Niewiasta Polska”, redaktor odpowiedzialny Katarzyna Płatek, ukazywał się w Krakowie w 1. 1899-1907. Od numeru 2 nosił podtytuł „Pisemko dla mieszczanek i gospodyń wiejskich”; przez pewien czas periodyk ukazywał się jako dodatek do "Zwiazku Chłopskiego”, potem był dodatkiem „Gazety Niedzielnej”; zob. Izabela Krasińska, "Niewiasta Polska" (1899-1907) jako przykład pisma patronackiego - zarys monograficzny”, Rocznik Biblioteki Naukowej PAU i PAN w Krakowie, R. LXII, 2017, 113-122.

11 Małgorzata Mirek, „Wkład Amelii Starowieyskiej w rozwój czytelnictwa kobiet”, w: Agnieszka Chamera-Nowak, Dariusz Jarosz (red.), Na co dzień i od święta. Książka w życiu Polaków w XIX-XXI wieku, (Warszawa: Oficyna Wydawnicza Aspra-JR, 2015), 403-420.
} 
Sług”, miesięczny dodatek do czasopisma "Grzmot”, potem zastąpiony przez "Głos Dziewczą Polskich”, firmowany przez Stowarzyszenie Sług Katolickich pod wezwaniem św. Zyty ${ }^{12}$. Przy tej okazji wypada wspomnieć, że rynek prasowy dla żeńskiej służby domowej był dość rozbudowany, o czym świadczyły także inne periodyki, jak warszawska „Pracownica Katolicka”, organ Stowarzyszenia Służących, wydawany i kierowany przez Marię Helenę Antoszewską. Przypadek drugi stanowił „Rocznik Katolickiego Zwiazku Kobiet Polskich" powstały w $1911 \mathrm{r}$., natomiast trzecim przypadkiem był ukazujący się od następnego roku miesięcznik „Kartka Miesięczna Kongregacji Ziemianek pod Wezwaniem Matki Boskiej Kochawińskiej”13. Przypadek czwarty dotyczył „Myśli Katolickiej”, pisma tygodniowego, organu katolików świeckich. Redaktorką była Lucyna Łopacińska, wydawczynią Janina Steinbok. Tygodnik ukazywał się od 1908 r. nakładem Zjednoczenia Pań o Działalności Katolickiej pod wezwaniem Matki Boskiej Częstochowskiej Królowej Korony Polskiej. Każdy $z$ wymienionych przypadków stanowił efekt aktywizacji środowiska katoliczek i wypracowywania reguł wychowawczej i edukacyjnej funkcji czasopiśmiennictwa światopoglądowego ${ }^{14}$. Wspomniane periodyki były dowodem rozmaitych form działalności formacyjnej, która pogłębiała przebieg procesu instytucjonalizacji katolickiego ruchu społecznego kobiet.

W Polsce międzywojennej podtrzymane zostały oczekiwania co do roli komunikacji społecznej podporządkowanej wartościom religijnym ${ }^{15}$. Podobnie jak uprzednio istniało Towarzystwo dla Popierania Prasy Katolickiej, zabiegano o powołanie Katolickiego Instytutu Prasowego dla krzewienia idei czasopiśmiennictwa światopoglądowego ${ }^{16}$. O znaczeniu prasy katolickiej wielokrotnie wy-

\footnotetext{
12 Joanna Morawska, „Wzorzec służącej propagowany na łamach katolickiego czasopisma "Przyjaciel Sług" na przełomie XIX i XX w.”, Czasopismo Naukowe Instytutu Studiów Kobiecych, nr 2, 2017, 23-40. W stopce redakcyjnej „Głosu Dziewcząt Polskich” jako wydawca figurowało Stowarzyszenie Sług św. Zyty.

13 Julia Terpiłowska, „Sekcja Społeczno-Wychowawcza”, Rocznik Katolickiego Zwiazku Kobiet $w$ Warszawie, 1911-1912, 10-12.

14 „Dlaczego nam potrzeba dzienników katolickich?”, Polak-Katolik, nr 298, 1907, 1-2.

15 „Popieranie prasy katolickiej przez duchowieństwo”, w: Pierwszy Zjazd przedstawicieli diecezjalnych organizacji kapłańskich w Rzeczypospolitej Polskiej w 1924 r. Pamiętnik Zjazdu, (Kielce: Drukarnia „Jedność”, 1925), 22; Czesław Stańczak, Katolicka akcja prasowo-kolportażowa. (Potrzeby, metody, środki), (Łódź: Biuro Ligi Katolickiej Diecezji Łódzkiej, 1930); Stanisław Kuraś, Potęga prasy, (Częstochowa: Drukarnia „Udziałowa”, 1933).

16 Józef Mazurek, Stwórzmy prase katolicka, czyli przyczyńmy się do rozszerzenia Towarzystwa dla Popierania Prasy Katolickiej, (Kraków: Towarzystwo dla Popierania Prasy Ka-
} 
powiadał się prymas Polski August Hlond, co wzmacniało pozycję czasopiśmiennictwa adresowanego do katoliczek. Duchowieństwo szczególnie doceniało periodyki ukierunkowane na przeciwdziałanie wpływom „nowoczesnego pogaństwa” identyfikowanego $z$ ideami liberalizmu społecznego ${ }^{17}$. Czasopisma katolickie umacniały wiarę religijna, dostarczały informacji o świecie odległym i bliskim (w tym o życiu parafialnym), przekazywały dane o życiu członkiń stowarzyszeń, uczestnicząc w kreowaniu tożsamości kobiet jako obywatelek państwa. Niezmieniony był porządek kulturowy, w którego centrum znajdowało się wierzenie religijne.

Rozwój prasy dla katoliczek w okresie międzywojennym stanowił następstwo zmiany sytuacji kobiet po Wielkiej Wojnie 1914-1918, gdy doszło do korekty stosunków społecznych. W publicystycznym przekazie prasowym dla Polek istniało przekonanie o tym, że procesy emancypacji kobiet były nieuchronnym skutkiem przekształceń demograficznych, społecznych, ekonomicznych, jakie zaszły w Europie i świecie wskutek rekonfiguracji ról społecznych pełnionych przez kobiety, gdy w warunkach wojennych uzupełniały pracę mężczyzn bądź zastępowały ich przy wykonywaniu obowiązków pracowniczych. Zwracano uwagę na powstanie warunków do tego, by żądać równych praw w sferze prywatnej i publicznej. Na łamach pisma „Kobieta Polska” (krakowska) w grudniu 1918 r. pojawiło się wyjaśnienie:

Dziś inne czasy. I tak się stać musiało, bo gdy kobieta stanęła obok mężczyzny w fabryce, przy warsztacie, w biurze, tym samym zrównała się co do praw z mężczyzna i weszła w życie publiczne. Dzisiaj kobiety maja swoje własne organizacje, gazety, zwołuja zebrania, przemawiaja, urządzaja zjazdy ${ }^{18}$.

W podobnym tonie wypowiadała się publicystka „Gazety dla Kobiet", stwierdzając, że

tolickiej, 1914); S. Wójcik, „O Katolicki Instytut Prasowy w Polsce”, Homo Dei, nr 6, 1936, 394-400.

17 Julia Kisielewska, „Piśmiennictwo katolickie jako broń w walce z nowoczesnym pogaństwem”, Wiadomości dla Duchowieństwa, nr 10-12, 1933, 267-269; „Kronika”, Ruch Katolicki, nr 8, 1934, 392; zob. Przemysław Sołga, „Prasa jako czynnik kształtujacy katolicka doktrynę medialna w XIX i XX wieku", Res Gestae. Czasopismo Historyczne, nr 3, 2016, 170-193.

18 „Udział kobiet w życiu politycznym”, Kobieta Polska (krakowska), nr 12, 1918, 1. 
kobietę w nowo powstałem państwie polskim wielkie czeka zadanie. W pierwszym rzędzie naturalnie najważniejsza jej pracą będzie zawsze wychowanie dzieci, stworzenie dzielnego, świadomego swych celów pokolenia, które pamiętne chwalebnych dziejów ojczystych nie zawaha się najdroższych swych skarbów złożyć w ofierze narodowi. Lecz nie tylko na tym polu czeka Was praca. Oto tysiące mężczyzn nie wróci już do zajęć zwykłych, do stanowisk dawniej zajmowanych - oto miejsca ustąpią nam ci, którzy dotąd na ziemi naszej gospodarowali i rządzili z barbarzyńska zuchwałościa - oto $z$ nowym ustrojem państwowym tyle nowych powstaje placówek, które zająć nam będzie trzeba koniecznie. Kobieta w czasie nieobecności mężów, braci i synów już przywykła do zajęć niegdyś przez mężczyzn tylko wykonywanych i nietrudno jej chyba będzie dziś, w zmienionych dla nas warunkach, w imieniu najświętszych umiłowań i obowiązku narodowego spełniać dalej swą pracę i zagonu nie opuszczać przed czasem ${ }^{19}$.

Dwa obszerne cytaty pochodzace $z$ łamów prasy dla katoliczek w okresie tworzenia niepodległego państwa polskiego zawierały jednoznaczne konstatacje nowego statusu kobiet. Zmiana została dostrzeżona w opiniotwórczych periodykach katolickich, wzmacniając wypowiedzi płynące ze środowisk kobiecych ${ }^{20}$.

Aktywizacja prasowa stanowiła rezultat przyznania kobietom praw wyborczych, co wzmogło zainteresowanie elektoratem żeńskim i możliwościa oddziaływania na wyniki walki o mandaty poselskie czy senatorskie ${ }^{21}$. Jeszcze przed 1918 r. w szeregach katoliczek objawiane były oczekiwania w sprawie upodmiotowienia kobiet, zagwarantowania praw politycznych, ugruntowania czynnika kobiecego w strukturze społecznej oraz docenienia roli w wychowaniu młodego pokolenia Polaków. W publicystyce prasowej znać było plan pozyskania wsparcia Kościoła w kierunku nadania Polkom uprawnień politycznych ${ }^{22}$. Rozstrzygające zdarzenia miały miejsce w trakcie działań państwowotwórczych jesienia 1918 r. Po-

\footnotetext{
19 „Polska jest!”, Gazeta dla Kobiet, nr 24, 1918, 24, 93.

20 Jan Urban, „O prawa obywatelskie dla kobiet”, Przeglad Powszechny, t. 138-139, 1918, 276-293; t. 139-140, 414-431. Tekst prasowy miał odbitkę w postaci broszury pod tym samym tytułem wydrukowana w Krakowie w 1918 r.

${ }_{21}$ Michał Śliwa, „Udział kobiet w wyborach i ich działalność parlamentarna”, w: Anna Żarnowska, Andrzej Szwarc (red.), Równe prawa i nierówne szanse: kobiety w Polsce międzywojennej. Zbiór studiów, (Warszawa: Wydawnictwo DiG, 2000), 49-59; Mariola Kondracka, Posłanki i senatorki II Rzeczypospolitej, (Warszawa: Wydawnictwo Sejmowe, 2017), passim.

22 Helena Wadowska, Maria Ekielska, „O stanowisku kobiety”, Sodalis Marianum, nr 1, $1917,12-19$.
} 
cząwszy od wyborów do Polskiego Sejmu Dzielnicowego w Poznaniu na przełomie listopada i grudnia 1918 r., kobiety miały możliwość skorzystania $z$ czynnego i biernego prawa głosu. Wzięły udział w głosowaniu, w którym status delegowanych (posłanek) do poznańskiego Sejmu m.in. uzyskały: Janina Omańkowska, Zofia Sokolnicka, Bronisława Szymkowiakówna, Franciszka Wilczkowiakowa. W Polsce niepodległej dzięki biernemu prawu wyborczemu zdobyły miejsca w Sejmie Ustawodawczym, a następnie także w Sejmie RP I kadencji (Sokolnicka) oraz w Sejmie Śląskim (Omańkowska). Mandaty poselskie pozyskały $z$ list Narodowego Komitetu Stronnictw Demokratycznych, złożonego $z$ osób należących do ND, ChD oraz ugrupowań pokrewnych. Oprócz parlamentarzystek $z$ byłej dzielnicy pruskiej w Sejmie i Senacie RP oraz w Sejmie Ślaskim w kolejnych latach znalazły się członkinie Narodowej Organizacji Kobiet (NOK).

W Polsce międzywojennej prasa dla katoliczek miała rozmaite odcienie: katolickie, narodowo-katolickie, narodowe, z uwzględnieniem różnych składników tradycjonalizmu i zachowawczości wobec spraw społecznych. Powielana była gotowość do przeciwdziałania wpływom wydawnictw prasowych i książkowych, przyczyniających się do demoralizacji młodzieży. Zalecenia dla katoliczek brzmiały następująco:

Prasa katolicka dająca nam wszystko co jest potrzebne dla życia i kształcenia, musi być przez nas znana i czytana. Brak zainteresowania wśród nas kobiet czytelnictwem spowodował, że młodzież na ogół mało czyta i mało umie, a jeżeli czyta, to pisma brukowe, bo nie ma jej kto nauczyć czytać prasy katolickiej. Tu jest olbrzymi teren naszej pracy ${ }^{23}$.

Powoływano się na stanowisko prymasa Hlonda, który oceniając czasopiśmiennictwo katolickie w Polsce, wyraził dezaprobatę periodyków zawierających informacje o aferach i skandalach obyczajowych („buduarowe sekrety”, „prasowe chuligaństwo”). Zalecenia przeciwdziałania negatywnym wpływom wrogów polskości i katolicyzmu wiązały się z zabiegami o umacnianie kultury czytania katolików. Redakcje zmierzały do uczynienia prasy lektura obo-

23 „Czytelnictwo”, Ogniwo. Okólnik Akcji Katolickiej Diecezji Lubelskiej, nr 1, 1933, 18; „Z naszego ruchu”, Polka, nr 8, 1926, 4; „Kurs dla prezesek, sekretarek i skarbniczek”, Głos Polek, nr 17, 1923, 4; „Nasz Związek”, Głos Dziewcząt Polskich, nr 2, 1929, 2-3; „Warto przeczytać”, Kobieta Polska (poznańska), nr 3, 1937, 12. 
wiązkowa ${ }^{24}$. Czytelniczki prasy katolickiej miały umieć odróżniać ja od czasopism, które szerzyły zło i zasługiwały na miano „pożal się Boże gazet”, wypełnionych „stekiem bzdur"25. W 1938 r. na łamach miesięcznika „Hasło Polki”, organu NOK, przypominano o roli kobiet $\mathrm{w}$ działaniach ochronnych przed siłami antypolskimi, antynarodowymi i antykatolickimi ${ }^{26}$.

Kształtowanie się prasy katolickiej, narodowo-katolickiej i narodowej dla kobiet było następstwem wieloczynnikowych przekształceń społecznych, ekonomicznych, politycznych w Polsce. Bezpośredni wpływ miała postawa Kościoła katolickiego, ale też istotne stało się działanie oddolne, gdy aktywistki katolickie podejmowały inicjatywy prasotwórcze. Funkcje prasy katolickiej wynikały z gotowości do szerzenia wiary religijnej integrowania środowiska katoliczek, edukowania w zakresie powinności wobec narodu, państwa, rodziny. Szczególną funkcją było strzeżenie stanu moralnego Polek i Polaków.

\section{Parametry formalno-techniczne, personalne i tematyczne}

Pod pojęciem prasy dla katoliczek znajdują się wydawnictwa periodyczne adresowane do kobiet o światopogladzie katolickim oraz o poglądach, zgodnie $z$ którymi naród znajduje się na czele systemu aksjologii politycznej. Ponadto w katalogu wartości mieściły się: państwo narodowe, rodzina, mowa ojczysta, tradycje, obyczajowość. Każdorazowo istotny był dobrostan narodowy identyfikowany $z$ ładem etyczno-moralnym opartym na Dekalogu. Wspomniany katalog był wzbogacony o derywaty narodu, jak: edukacja narodowa, ekonomika narodowa, kultura narodowa, terytorium narodowe, życie narodowe. Szczególną kategorią było państwo narodowe, w dużej mierze monoetniczne i monokulturowe.

\footnotetext{
24 Autoreklama, tworzenie kanałów dystrybucji „dobrej prasy”, do której oprócz periodyków adresowanych do kobiet zaliczono pisma: „Mały Dziennik”, „Posłaniec Serca Jezusowego”, „Przewodnik Katolicki”, „Rycerz Niepokalanej”, „Słowo Katolickie”. Powyższe tytuły prasowe zostały uwzględnione w notce informacyjnej na temat miejsc sprzedaży periodyków katolickich, zob.: „Jak rozwija się kiosk "dobrej prasy“ w Koluszkach”, Gazeta dla Kobiet, nr 3, 1937, 29; „Pisząc o zadaniach prasy”, Dzwon Niedzielny, nr 13, 1936, 205.

25 "Cele Polskiego Związku Niewiast Katolickich”, Niewiasta Katolicka, nr 4, 1931, 1; Pelagia Restorffowa, „Zjazd w Częstochowie”, Gazetka dla Kobiet, nr 9, 1924, 2.

26 Bronisława Kraupe, „Etyka żydowska i katolicka”, Hasło Polki, nr 6, 1938, 1-2.
} 
W definicyjnym ujęciu prasy katolickiej, katolicko-narodowej i narodowej mieściło się czasopiśmiennictwo, którego cecha była niezbyt uchwytna odrębność kategorialna pojęć takich, jak „prasa religijna”, „prasa wyznaniowa”, w mniejszym stopniu „prasa kościelna" ${ }^{27}$. W tym wypadku istotnym kryterium delimitacji prasy światopoglądowej były dwie kwestie. Pierwsza - natury formalnej - wiązała się z obecnością duchownego katolickiego, który sprawował patronat nad periodykiem i nadzorował jego zgodność $z$ nauką Kościoła. Druga - natury merytorycznej - wiązała się z profilem tematycznym pisma i przekładała się na publikowanie tekstów poświęconych wydarzeniom religijnym, żywotom świętych katolickich. Natomiast nie było trudności $z$ wyodrębnieniem $z$ pojęcia „narodowa prasa katolicka” podzbioru „narodowa prasa dla katoliczek" o cechach czasopiśmiennictwa społecznego. Była wydawana przez NOK, wkomponowujac się w rozbudowany system prasowy ND, której kierownictwo dbało o pełny przekrój społeczny i terytorialny czasopiśmiennictwa ukierunkowanego na masowego odbiorcę ${ }^{28}$. Tworzyła prasę dla młodzieży, weteranów i kombatantów, Kresowiaków, związków zawodowych „Praca Polska”, inteligentów, rzemieślników, chłopów i robotników. Powstanie periodyków adresowanych do kobiet dopełniało wspomniany system prasowy, zasilając go o czasopiśmiennictwo światopoglądowe dla czytelniczek. Aktywność członkiń NOK wzmacniała zaangażowanie prasotwórcze w całym kraju. Rozwój czasopiśmiennictwa narodowego był normowany stanem prawnym, ograniczeniami cenzorskimi, kondycja finansowa. Szczególny wpływ na stan prasy narodowej miała decyzja papieża Piusa XI o wpisaniu dziennika „L'Action Française” do indeksu ksiag zakazanych. W ten sposób potępiona została działalność Akcji Francuskiej, skrajnie prawicowej, monarchistycznej i nacjonalistycznej grupy pod kierunkiem Charles'a Maurrasa, zmierzając do ochrony katolików przed narastaniem ekstremizmu

27 Czesław Lechicki, „Prasa katolicka Drugiej Rzeczypospolitej”, Kwartalnik Historii Prasy Polskiej, nr 2, 1984, 45-46; Sylwester Dziki, „Prasa wyznaniowa”, w: Walery Pisarek (red.), Słownik terminologii medialnej, (Kraków: Towarzystwo Autorów i Wydawców Prac Naukowych „Universitas”, 2006), 156.

28 Ewa Maj, „O pożytkach z badania prasy Narodowej Demokracji (do 1939 r.)”, w: Agnieszka Łukasik-Turecka, Konrad Słowiński (red.), Logos i ethos w polityce. Ksiega jubileuszowa Profesora Stanisława Wójcika, (Lublin: Wydawnictwo Katolickiego Uniwersytetu Lubelskiego, 2020), 539-552. 
politycznego ${ }^{29}$. Jednak w wypadku czasopiśmiennictwa ukierunkowanego na kobiety nie objawiła się ewolucja właściwa ogólnoinformacyjnej i ideotwórczej prasie narodowej - od indyferentyzmu religijnego do identyfikacji etniczno-konfesyjnej.

Dobór próby badawczej nastąpił wskutek zastosowania kryteriów selekcji materiałów we wspomnianych na wstępie dwóch wariantach: szerszym - dla ogółu zwolenniczek czy sympatyczek programu katolicko-narodowego oraz węższym - dla członkiń stowarzyszeń społecznych i/bądź ugrupowań politycznych. W ten sposób korpus badawczy wypełniły czasopisma: „Chrześcijańska Służąca Polska”, „Gazeta dla Kobiet”, „Gazeta Kobiet”, „Gazetka dla Kobiet”, "Głos Dziewcząt Polskich”, "Głos Kobiety”, "Głos Polek”, "Głos Wielkopolanek”, „Hasło Polki”, „Kobieta Polska” (krakowska), „Kobieta Polska” (poznańska), „Kobieta Wielkopolska”, „Kuźniczanka”, „Matka i Gospodyni”, „Młoda Polka”, „Niewiasta Katolicka”, „Pisemko Kuźniczanek”, „Polka”, „Pracownica Polska”, „Własnymi Siłami”, „Współczesne Życie Kobiet”, „Ziemianka”, „Ziemianka Polska” „Zjednoczenie”, „Życie Kobiet”. Cechy czasopiśmiennicze, ale bez niektórych komponentów przynależnych pełnym periodykom miały: „Tydzień Kobiecy” - wkładka w numerze „ABC. Nowiny Codzienne” czy „Sprawy Kobiece”, dodatek do „Głosu Pomorskiego”, a ponadto "Głos Polek. Jednodniówka”, nakładem NOK. Poza korpusem mieściło się czasopiśmiennictwo tercjarskie oraz periodyki zgromadzeń zakonnych.

Pod pojęciem katolickiej, katolicko-narodowej i narodowej prasy dla kobiet znalazły się periodyki, w których (1) deklarowano światopogląd religijny $z$ uwzględnieniem narodu jako wartości najwyższej w życiu doczesnym; (2) przetwarzano informacje o sytuacji Kościoła katolickiego, relacjonowano przebieg Kongresów Eucharystycznych, prezentowano wiedzę o doktrynie religijnej, a watki eschatologiczne przeplatały się $z$ zagadnieniami świętości życia, $z$ promowaniem żywotów kobiet kanonizowanych czy beatyfikowanych; (3) starano się pogłębić życie duchowe kobiet, animować i wzmacniać działalność w organizacjach społecznych; (4) informowano o sytuacji społecznej w Polsce i świecie. W winiecie miały wezwanie „Z Bogiem dla Ojczyzny” bądź „Bóg - Rodzina - Ojczyzna”.

\footnotetext{
29 Za pontyfikatu Piusa XII sankcje zostały zdjęte na mocy dekretu Świętego Oficjum z 5.07.1939 r.; zob. Bogdan Szlachta, „Action Française”, w: Michał Jaskólski (red.), Słownik historii doktryn politycznych, t. 1, (Warszawa: Wydawnictwo Sejmowe, 1997), 17-20.
} 
Cechą wspólna prasy katolickiej, katolicko-narodowej i narodowej był światopogląd, natomiast zróżnicowanie dotyczyło: (1) okresu istnienia - w próbie badawczej znalazły się periodyki długotrwałe, krótkotrwałe, efemerydalne; (2) proweniencji - organy instytucji oraz periodyki powołane $z$ inicjatywy indywidualnej wybitnych postaci kobiecych; (3) formy i typu czasopiśmienniczego - w korpusie umieszczone zostały periodyki regularne w postaci tygodników i miesięczników, a także jednodniówki, biuletyny, okólniki, sprawozdania, dodatki samoistne oraz niesamoistne w postaci: kącika, rubryki lub jednostronicowego działu dla kobiet; (4) nakładcy - afiliacje w postaci stowarzyszenia społecznego czy ugrupowania politycznego; (5) rozmieszczenia terytorialnego $z$ wyszczególnieniem ośrodków wydawniczych, jak: Bielsko, Bytom, Cieszyn, Katowice, Kórnik, Kuźnice, Lublin, Poznań, Tarnów, Warszawa, Wilno.

Odbiorczyniami były kobiety „wszystkich stanów”, ale w niektórych wypadkach ukonkretniano wizję czytelniczki pod względem statusu społecznego. Pozycjonowanie na rynku prasowym spowodowało, że część periodyków trafiała w ręce mieszkanek miast, w tym robotnic, rzemieślniczek, a także nauczycielek czy urzędniczek („Polka”), inna część była adresowana do mieszkanek wsi („Ziemianka” i „Ziemianka Polska”), a ponad podziałami terytorialnymi były druki przeznaczone dla żeńskiej służby domowej („Chrześcijańska Służąca Polska”, „Pracownica Polska” czy „Głos Dziewcząt Polskich”). Ze względu na odbiorczynie stosowane środki perswazyjne były uproszczone, niekiedy wręcz zredukowane do najbardziej elementarnych uzasadnień przekazywanych treści społecznych. Nakładem stowarzyszeń publikowane były książki i broszury, dzięki którym przekaz społeczny był znacznie poszerzony.

W powyższym wykazie czasopiśmienniczym znalazły się organy zrzeszeń społecznych dla katoliczek. Przykładowo periodyki dla kobiecej służby domowej były firmowane przez Polski Związek Zawodowy Chrześcijańskiej Służby Domowej („Chrześcijańska Służąca Polska”, „Pracownica Polska”) oraz Stowarzyszenie Sług Świętej Zyty („Głos Dziewcząt Polskich”), założonego w 1899 r. przez jezuitę Włodzimierza Ledóchowskiego. Część periodyków przeznaczonych dla kobiet pracujących w fabrykach i zakładach rzemieślniczych tworzyły członkinie Katolickiego Zwiazku Polek, powstałego w 1906 r. jako Katolicki Związek Kobiet Polskich - zmiana nazwy nastapiła w 1915 r. Wśród periodyków zakwalifikowanych 
do węższego kręgu mieściły się organy stowarzyszeń o charakterze (1) politycznym, jak NOK - „Gazetka dla Kobiet”, „Głos Polek”; (2) partyjnym $-z$ Narodową Partią Robotniczą identyfikowały się pisma „Głos Kobiety” oraz „Polka”, a ze Zjednoczeniem Mieszczańskim był zwiazany „Głos Wielkopolanek”30; (3) parapolitycznym, jak Stowarzyszenie Ziemianek Polskich, w którego gestii znajdowały się dwa kolejne czasopisma: „Ziemianka” oraz „Ziemianka Polska”; (4) apolitycznym, gdy animatorkami prasy były członkinie ruchu katolików świeckich w szeregach Akcji Katolickiej. Wśród periodyków powołanych z inicjatywy indywidualnej wyróżniły się: „Pisemko Kuźniczanek” i „Kuźniczanka”, dwa organy Szkoły Domowej Pracy Kobiet w Zakopanem, powołanej przez Jadwigę Zamoyską i kontynuowanej przez jej córkę Marię Zamoyska ${ }^{31}$. Różnorodną działalność prasotwórcza prowadziła Zofia Zaleska, posłanka na Sejm Rzeczypospolitej Polskiej III kadencji. Współtworzyła istotne czasopisma: „Gazetka dla Kobiet”, „Życie Kobiet”, „Współczesne Życie”, „Współczesne Życie Kobiet”, wraz z Wanda Ładziną (posłanka na Sejm RP I kadencji) wydała „Kalendarz Pani Domu na Wsi i w Mieście”, ponadto w 1927 r. redagowała "Głos Rodziców”, organ Zjednoczenia Zrzeszeń Rodzicielskich w Polsce. Występowała w podwójnej roli: czynnej dziennikarki oraz historyczki czasopiśmiennictwa adresowanego do kobiet, gdy w 1938 r. pod firma Warszawskiej Szkoły Dziennikarskiej wydała monografię, majaca do dzisiaj wpływ na badania dziejów periodyków dla czytelniczek ${ }^{32}$.

Wydawczynie, redaktorki, publicystki tworzyły środowisko dziennikarek katolickich, niekiedy nazywanych "gazeciarkami” ze względu na nie do końca unormowaną nomenklaturę zawodową ${ }^{33}$.

\footnotetext{
30 „Nasi kandydaci”, Głos Wielkopolanek, nr 43, 1922, 1-2, 4. W wyborach 1922 r. redakcja poparła Kazimierza Krotoskiego, ponieważ „był znany jako gorący obrońca katolickiej zasady czy w wychowaniu szkolnym, czy w życiu publicznym”. Krotoski, nauczyciel, historyk, publicysta, współtworzył Stronnictwo Katolicko-Narodowe w Krakowie, następnie należał do Stronnictwa Mieszczańskiego, a po jego likwidacji działał w ChD.

31 Zob. Maria Zamoyska, Wspomnienia, (Kórnik: Fundacja Zakłady Kórnickie, 2017), 91-112nn.

32 Zofia Zaleska, Czasopisma kobiece w Polsce. (Materiały do historii czasopism). Rok 1818 1937, (Warszawa: Wyższa Szkoła Dziennikarska, 1938).

33 Nazewnictwo wiązało się $z$ misyjną funkcją pracy dziennikarskiej, czym nawiąywano do papieskich wypowiedzi, w których znalazły się wzmianki o posłannictwie (Pius X), czy do wcześniejszej Leona XIII o „Żołnierzach prasy”, zob. K. Ż. K [Witold Klimkiewicz, Karol Knitter, Felicja Żurowska], Gazeciarka - apostołka, (Poznań: Wydawnictwo Katolickiego Związku Młodzieży Żeńskiej, 1935).
} 
W jego gronie wyróżniały się: Maria Czeska-Mączyńska, Elżbieta Estreicherowa, Helena Erzepki, Maria Holder-Eggerowa, Irena Puzynianka, Pelagia Restorffowa, Zofia Rzepecka, Lucyna Sieciechowiczowa, Franciszka Wilczkowiakowa, Zofia Zajaczkowa, Zofia Zaleska, Aniela Zdanowska, Felicja Żurowska. W tym gronie były panie podejmujące działalność społeczna, angażujące się $\mathrm{w}$ pracę dla dobra wspólnego w skali lokalnej i krajowej. Znalazły się $\mathrm{w}$ nim posłanki, radne miejskie, działaczki samorządowe, aktywistki stowarzyszeń społecznych, animatorki życia miejscowego. Poza aktywnością organizacyjną w stowarzyszeniach, angażowały się w kolejne inicjatywy wydawnicze. W ten sposób pomnażały krag odbiorczy czasopiśmiennictwa światopoglądowego. Przykładem mogła służyć działalność Felicji Żurowskiej, która redagowała miesięcznik „Scena Oświatowa”, ukazujący się w latach 19341939. Periodyk zawierał wskazówki użyteczne przy uatrakcyjnieniu zebrań Katolickiego Związku Młodzieży Żeńskiej i Katolickiego Związku Młodzieży Męskiej. Dokonywała dywersyfikacji form logistycznych w pracy pro bono, znanej z biograficznych doświadczeń pozostałych pań zaangażowanych $\mathrm{w}$ prowadzenie czasopiśmiennictwa światopoglądowego.

Prasa dla katoliczek pełniła podstawowe funkcje czasopiśmiennicze. Redakcje dbały o serwis informacyjny, ale nade wszystko troszczyły się o rozwijanie sfery perswazyjnej, wypełniając poszczególne numery periodyków materiałami o treści religijnej i patriotycznej. Temu zadaniu służyła struktura egzemplarza prasowego, tak zbudowana, by artykuł wstępny zawierał przewodni motyw ideowy, a pozostałe teksty, w tym artykuły analityczne i komentatorskie, a także felietony, pogawędki, były mu podporządkowane, niejako rozpisujacc na poszczególne gatunki wybrane sekwencje tematyki głównej. Bywały też przykłady bardziej różnorodnej struktury tekstów oraz ich problematyki, gdy w danym numerze periodyku w pojedynczych rubrykach opisywano różne sprawy z życia społecznego w Polsce i na świecie. Niewatpliwie konsekwentnie zmierzano do kształtowania poglądów katoliczek na żywotne kwestie światopoglądowe, prezentując punkt widzenia zespołu redakcyjno-publicystycznego w odniesieniu do obserwowanych zjawisk laicyzacji postaw i zachowań ludzkich, podejścia do zagadnienia nierozerwalności małżeństwa czy nienaruszalności życia człowieka, ochrony macierzyństwa, troski o obyczajność zachowań spo- 
łecznych. W poczuciu zagrożenia wypowiadano się o spadku liczby urodzeń, o rozwodach, o związkach niesakramentalnych, o parach nieheteronormatywnych ${ }^{34}$. Stały był udział w kolejnych odsłonach dyskusji na temat aborcji, rozpatrywanej pod względem eugenicznym, gdy przypominano, że „spadek liczby urodzin w lepszych rodzinach” prowadził do „niczym nieskrępowanego rozrostu mniej wartościowych osobników"35. Publicystyka prasowa odnosiła się do zjawiska nazwanego niechęcia do dzieci, polegającego na regulacji urodzeń wskutek utrwalania poglądu, że postęp polega na ochronie przed przeludnieniem i brakiem żywności. Na łamach periodyku „Niewiasta Katolicka” tłumaczono czytelniczkom, jak samobójcza była to polityka części ludzkości, podlegającej niebezpiecznym pradom myślowym. Przekonywano, że „bezdzietność nie jest choroba ciała, lecz zaraza duszy"36.

Istotnym składnikiem pracy dziennikarskiej była funkcja organizatorska i integracyjna środowisk katoliczek powiazana $z$ wyzwalaniem chęci pracy społecznej. Czytelniczkom, szczególnie $z$ uboższych grup pracowniczych, zalecano włączenie się w działalność stowarzyszeniową. W tym względzie prasa służyła poradami, podając sposoby tworzenia struktury organizacyjnej oraz pouczajacc o metodach aktywizacji pracy społecznej. Szczegółowy instruktaż zawierał dane o technikach budowania relacji międzyludzkich, kształtowania podstawowych kółek organizacyjnych oraz prowadzenia działalności, zaznaczając, że

kółko takie oczywiście nie może istnieć bez kierownika naukowego, który daje objaśnienia i wskazówki. Kierownikiem tym będzie zazwyczaj Ks. patron, wicepatron, pani radna lub uproszona do tego pani $z$ inteligencji gruntownie wykształcona i chętna ${ }^{37}$.

\footnotetext{
$34 \quad$ W wypowiedziach publicystycznych były obalane mity na temat rzekomych korzyści płynących z rozwodów dla kobiet, które inaczej niż Amerykanki nie mogły liczyć na zachowanie prawa do dzieci oraz na alimentację ze strony byłego męża. Czytelniczkom tłumaczono, że oprócz trudności z zabezpieczeniem materialnej strony życia rozwódki istniały także inne negatywne skutki rozwiąania małżeństwa, takie jak krzywda dzieci, osamotnienie, predyspozycje do rozwiazłości. „Zyski rozwódek”, Niewiasta Katolicka, nr 8, 1931, 3; „Przemysł rozwodowy", Niewiasta Katolicka, nr 2, 1932, 4.

35 „Oświadczenie lekarzy”, Niewiasta Katolicka, nr 8, 1931, 4; Elżbieta Estreicherowa, „Matkom zmarlych dzieci”, Matka i Gospodyni, nr 3, 1929, 65-67.

36 „Śmierć albo życie”, Niewiasta Katolicka, nr 10, 1931, 3; „Bezwyznaniowość a spadek urodzin”, Niewiasta Katolicka, nr 3, 1932, 3; „Przeciw ograniczaniu potomstwa”, Głos Wielkopolanek, $\mathrm{nr}$ 30, 1922, 6.

37 „Kółka oświatowe”, Gazeta dla Kobiet, nr 22, 1918, 85.
} 
Lista osób wspierających pracę stowarzyszeniową na podstawowym poziomie oznaczała, że w praktyce realizowano zasadę solidaryzmu społecznego, przynajmniej na etapie kreowania wpływając na poczynania najniższych instancji stowarzyszeniowych. Upowszechniano wiedzę poradnikowa, zgodnie $z$ która kierowniczki („kółkowe”) pracy podstawowej dowiadywały się, jak z pomoca proboszcza, a także świeckiego opiekuna i doradcy, przygotowywać referaty, prelekcje, pogadanki, żeby były „podniosłe i pouczające”. Zalecano podejmowanie prac integrujących lokalne środowisko, w tym celu organizujac dziecięce kółka śpiewacze, przygotowując okolicznościowe spotkania świąteczne ${ }^{38}$. W bardziej rozwiniętej postaci działań formacyjnych propagowano zakładanie tanich jadłodajni, dziecięcych i młodzieżowych świetlic, czytelni katolickich. Obowiązkowa stawała się rytualizacja pracy stowarzyszeniowej: ufundowanie sztandaru organizacyjnego, zamawianie okolicznościowych nabożeństw wotywnych, chóralne śpiewanie pieśni religijnych i patriotycznych, które spotkaniom dodawały odświętnego charakteru. W celu sprostania wymogom pracy stowarzyszeniowej propagowano znaczenie instruktorek, zachęcano do uczestnictwa w kursów edukacyjnych, dzięki czemu upowszechniana była wiedza o budowaniu pozytywnych relacji między członkiniami i kierownictwem ${ }^{39}$.

W miarę zmian społecznych zachodzacych w międzywojniu pojawiały się wzmianki o wyłomach $\mathrm{w}$ patriarchalnym porządku społecznym, informujące czytelniczki o tym, że kobiety podejmowały się zadań dotychczas zarezerwowanych dla mężczyzn. Opisywano przypadki wchodzenia kobiet do zawodów „męskich” w sądownictwie, urzędach publicznych, medycynie. Wprawdzie stereotypy płci powodowały, że w wizerunkach kobiet utrwalały się odniesienia do kobiecości interpretowanej jako kwintesencja dobroci, pracowitości, empatii, ale znać było poczucie zmian obyczajowych, ponieważ „znikły już dawne podlotki, które miały dość czasu na spisywanie

\footnotetext{
38 Aleksandra Grzybowska, „Korzyści, jakie nam daje stowarzyszenie”, Ziemianka Polska, nr 19, 1926, 3-5; „Czego wymaga życie obecne od kobiety”, Niewiasta Katolicka, nr 1, 1931, 1; Abecadło Młodej Polki. (Wskazówki życiowe), (Lisków: Katolickie Stowarzyszenie Kobiet, 1938).

39 „Kurs dla prezesek, sekretarek i skarbniczek”, Głos Polek, nr 17, 1923, 4; „Z ruchu w Stowarzyszeniach”, Kobieta Polska (krakowska), nr 4, 1920, 4-5; Aniela Zdanowska, „Kursy dla kobiet”, Gazetka dla Kobiet, nr 6, 1924, 1-2; zob. Janina Sobkowiakówna, Poradnik prawny dla Katolickich Stowarzyszeń Kobiet i ich oddziałów, (Poznań: KZK, 1937).
} 
swoich marzen w osobistych pamiętnikach" ${ }^{40}$. W wielu sytuacjach aprobatywnie opisywano obecność w przestrzeni publicznej kobiet wykształconych, swiadomych sytuacji narodu i państwa, kompetentnych $\mathrm{w}$ sprawach zarzadzania zasobami ludzkimi. Korekcie podlegały wcześniej ustalone poglądy na temat pracy zawodowej kobiet. Obok niewzruszonego przekonania o prymarnych obowiąkach macierzyńskich zaczęły się wzmagać skłonności do rewidowania podejścia do możliwości podejmowania pracy zawodowej nie tylko $z$ powodów ekonomicznych, dopuszczając możność realizacji kobiecych uzdolnień i predyspozycji do określonych profesji, głównie w dziedzinie opiekuńczo-wychowawczej ${ }^{41}$. Nadal stosowano samowykluczenie $\mathrm{z}$ niektórych sfer życia zawodowego, $\mathrm{z}$ części rytuałów i symboli narodowych. Zarazem przekaz prasowy mieścił w sobie przekonanie, że zagadnienie płci - poza konwencjonalnym porządkiem świata kobiecego i świata męskiego - nie wymagało odrębnego traktowania, ponieważ uznawano je za składnik dziedzictwa narodowego.

Wprawdzie incydentalnie, ale pojawiały się głosy nieufności wobec polityki uprawianej przez mężczyzn, szczególnie w atmosferze narastania zagrożenia wojennego: „Nie łudźmy się, że wielcy mężowie świata potrafia doprowadzić państwa do rozbrojenia"42. Refleksje dotyczące przekształceń w sytuacji kobiet wskutek wielkiego kryzysu gospodarczego skłaniały do publicystycznych wypowiedzi $\mathrm{w}$ sprawach przeciwdziałania dyskryminacji kobiet $\mathrm{w}$ kwestii partycypacji w życiu publicznym, rynku pracy, wyzysku i nierówności płac, ograniczeń awansu zawodowego. Dużo miejsca zajmowały zagadnienia dysfunkcji systemu prawnego w kwestii likwidowania nierządu i handlu dziećmi i kobietami czy przeciwdziałania alkoholizmowi mężczyzn. Nadal jednak niezmienne pozostawało uni-

\footnotetext{
40 „Dwojakość w powołaniu żeńskim”, Niewiasta Katolicka, nr 1, 1932, 1; „Musimy się kształcić!”, Młoda Polka, nr 10, 1937, 143; „Udział kobiet w XVIII sesji Ligi Narodów”, Kobieta Wielkopolska, nr 1, 1936, 4-5.

41 Pełne wymowy społecznej były życzenia noworoczne zamieszczone w 1930 r. na pierwszej stronie „Gazety dla Kobiet”, w których znalazły się zalecenia: „Paniom nauczycielkom, żeby częściej aniżeli dotychczas osiągały posadę kierowniczą w szkołach żeńskich. Radom parafialnym, magistratom i radom miejskim - niech obok rozumnego męża radzi światła kobieta”, „Na Nowy Rok!”, Gazeta dla Kobiet, nr 1, 1930, 1; „Praca matek poza domem”, Niewiasta Katolicka, nr 12, 1932, 1; „Zagadnienie pracy kobiet na Międzynarodowej Konferencji Pracy”, Gazeta dla Kobiet, nr 9, 1930, 82.

42 „O czym wiedzieć i w obronie czego muszą stanąć kobiety?”, Głos Kobiety, nr 5, 1931, 2; „Pokój a niewiasta”, Niewiasta Katolicka, nr 11, 1931, 2.
} 
kanie „wojny płci”, poza wzmiankowanymi wyłomami w systemie patriarchalnym nie podejmowano prób jego obalania, co więcej umacniano konwencjonalny wizerunek statecznej i odpowiedzialnej kobiety, mającej obowiązek wychowania młodej generacji. Wzorce Polki-katoliczki i Matki-Polki powielały schematy systemu patriarchalnego i reprodukowały archetypiczne cechy kobiecości identyfikowanej z rodziną i macierzyństwem Chętnie upowszechniano model "cichej bohaterki”, która oddawała się pracy na rzecz dobrostanu narodu i katolicyzmu. W obliczu zagrożeń moralnych, obyczajowych, etycznych, gdy objaśniany w prasie świat był miejscem narastającego totalitaryzmu politycznego, nieposzanowania życia ludzkiego, deprecjonowania godności człowieka, publicystki wykazywały poczucie siły czerpanej $z$ wierzenia religijnego, co wyraziła Zofia Rzepecka, znana i ceniona aktywistka Akcji Katolickiej, stwierdzając w czasopiśmie „Zjednoczenie”, że „mamy jasno wytknięte cele i mamy pewność drogi, która wiedzie do ich zrealizowania. Jakież to szczęście w chaosie dzisiejszego świata!"43.

Wśród cech czasopiśmiennictwa ukierunkowanego na katoliczki zwracały uwage następujące właściwości: (1) brak periodyków codziennych - według kryterium frekwencyjne były tygodniki, dwutygodniki i miesięczniki; (2) skład redakcji z udziałem aktywistek stowarzyszeń o charakterze wyznaniowym i narodowym; (3) ukierunkowanie na czytelniczki formalnie bez segmentacji ze względu na status społeczny, ale faktycznie każdorazowo widoczne było rozeznanie w specyfice grupy docelowej; (4) poczucie niedostatku wyrazistego oddźwięku treści prasowych w makroskali życia społecznego Polski, ale za to istniała świadomość wpływu na środowiska katoliczek, szczególnie zorganizowanych w stowarzyszeniach. Ostatnia cecha wynikała $z$ ogólnej sytuacji prasy dla kobiet, która nie miała cech właściwych masowym ośrodkom wpływu na opinię publiczną. Natomiast znajdowała oddźwięk w środowiskach kobiecych zorientowanych na aktywizację na rzecz spraw własnych i otoczenia społecznego.

$\overline{43}$ Zofia Rzepecka, „Na progu Nowego Roku”, Zjednoczenie, nr 1, 1934, 3. 


\section{Zakończenie}

Katolicka, katolicko-narodowa i narodowa prasa dla kobiet wyrażała oczekiwania środowisk zorganizowanych w struktury stowarzyszeniowe, ale też obrazowała zmiany warunków społecznych w Polsce i świecie w latach 1918-1939. Publicystki opisujace przekształcenia warunków życia dawały dowody starannego obserwowania wydarzeń i ludzi, a niekiedy też aranżowania okoliczności przekazu treści politycznych, łącznie $z$ agitowaniem na rzecz katalogu wartości narodowych i katolickich. Gruntowały wiedzę o normach kulturowych ukierunkowanych na kobiety w warunkach zdominowanych przez system patriarchalny.

Od początku obecności w Polsce niepodległej prasa katolicka, katolicko-narodowa i narodowa dbała o pełna korelację między toposem Polki i katoliczki. Stan iunctim etniczno-religijnego należał do rudymentów myślenia o sprawach polskich i miał swój punkt odniesienia w postaci wzorca Polki-katoliczki, dopełnianego ideałem Matki-Polki. W obu wypadkach wyobrażenie kobiety miało podłoże moralno-religijne, odzwierciedlone w przekazie prasowym.

\section{Bibliografia}

\section{Źródla}

Abecadło Młodej Polki. (Wskazówki życiowe), (Lisków: Katolickie Stowarzyszenie Kobiet, 1938).

„Bezwyznaniowość a spadek urodzin”, Niewiasta Katolicka, nr 3, 1932, 3.

„Cele Polskiego Zwiąku Niewiast Katolickich”, Niewiasta Katolic$k a, \mathrm{nr} 4,1931,1$.

"Czego wymaga życie obecne od kobiety”, Niewiasta Katolicka, nr 1, 1931, 1.

"Czytelnictwo”, Ogniwo. Okólnik Akcji Katolickiej Diecezji Lubelskiej, nr 1, 1933, 18.

„Dlaczego nam potrzeba dzienników katolickich?”, Polak-Katolik, nr 298, 1907, 1-2.

„Dwojakość w powołaniu żeńskim”, Niewiasta Katolicka, nr 1, 1932, 1. 
Estreicherowa, Elżbieta. „Matkom zmarłych dzieci”, Matka i Gospodyni, nr 3, 1929, 65-67.

Grzybowska, Aleksandra. „Korzyści, jakie nam daje stowarzyszenie", Ziemianka Polska, nr 19, 1926, 3-5.

„Jak rozwija się kiosk "dobrej prasy" w Koluszkach”, Gazeta dla Kobiet, nr 3, 1937, 29.

Kisielewska, Julia. „Piśmiennictwo katolickie jako broń w walce z nowoczesnym pogaństwem", Wiadomości dla Duchowieństwa, nr 10-12, 1933, 267-269.

„Kółka oświatowe”, Gazeta dla Kobiet, nr 22, 1918, 85.

Kraupe, Bronisław. „Etyka żydowska i katolicka”, Hasło Polki, nr 6, 1938, 1-2.

„Kronika”, Ruch Katolicki, nr 8, 1934, 392.

Kuraś, Stanisław. Potęga prasy, (Częstochowa: Drukarnia „Udziałowa", 1933).

„Kurs dla prezesek, sekretarek i skarbniczek”, Głos Polek, nr 17, 1923, 4.

K. Ż. K. [Witold Klimkiewicz, Felicja Żurowska, Karol Knitter]. Gazeciarka-apostołka, (Poznań: Wydawnictwo Katolickiego Związku Młodzieży Żeńskiej, 1935).

Mazurek, Józef. Stwórzmy prase katolicka, czyli przyczyńmy się do rozszerzenia Towarzystwa dla Popierania Prasy Katolickiej, (Kraków: Towarzystwo dla Popierania Prasy Katolickiej, 1914).

„Musimy się kształcić!”, Młoda Polka, nr 10, 1937, 143.

„Na Nowy Rok!", Gazeta dla Kobiet, nr 1, 1930, 1.

„Nasi kandydaci”, Głos Wielkopolanek, nr 43, 1922, 1-2, 4.

„Nasz Związek”, Głos Dziewcząt Polskich, nr 2, 1929, 2-3.

„O czym wiedzieć i w obronie czego muszą stanąć kobiety?”, Głos Kobiety, nr 5, 1931, 2.

„Od Redakcji”, Teologia Praktyczna, nr 1, 1939, 4.

"Oświadczenie lekarzy”, Niewiasta Katolicka, nr 8, 1931, 4.

"Pisząc o zadaniach prasy”, Dzwon Niedzielny, nr 13, 1936, 205.

„Pokój a niewiasta”, Niewiasta Katolicka, nr 11, 1931, 2.

„Polska jest!”, Gazeta dla Kobiet, nr 24, 1918, 24, 93.

„Popieranie prasy katolickiej przez duchowieństwo”, w: Pierwszy Zjazd przedstawicieli diecezjalnych organizacji kapłanskich w Rzeczypospolitej Polskiej w 1924 r. Pamiętnik Zjazdu, (Kielce: Drukarnia „Jedność”, 1925), 22. 
„Praca matek poza domem”, Niewiasta Katolicka, nr 12, 1932, 1. „Przeciw ograniczaniu potomstwa”, Głos Wielkopolanek, $\mathrm{nr} 30$, 1922, 6.

„Przemysł rozwodowy”, Niewiasta Katolicka, nr 2, 1932, 4.

Radziwiłł, Franciszek. „Znaczenie i potrzeby prasy katolickiej”, w: Jan Pawelski (red.), Pamiętnik Zjazdu Skargowskiego w Krakowie w dniach 25 i 26 września 1912 r., (Kraków: Drukarnia Eugeniusza i Kazimierza Koziańskich, 1912), 34-49.

Restorffowa, Pelagia. „Zjazd w Częstochowie”, Gazetka dla Kobiet, nr 9, 1924, s. 2.

Rzepecka, Zofia. „Na progu Nowego Roku”, Zjednoczenie, nr 1, 1934, 3.

Sapieha, Adam. „Mowa zamykająca wiec”, w: Jan Pawelski (red.), $\mathrm{Pa}$ miętnik Zjazdu Skargowskiego $w$ Krakowie $w$ dniach 25 i 26 września 1912 r., (Kraków: Drukarnia Eugeniusza i Kazimierza Koziańskich, 1912), 187-189.

Sobkowiakówna, Janina. Poradnik prawny dla Katolickich Stowarzyszeń Kobiet $i$ ich oddziałów, (Poznań: KZK, 1937).

Stańczak, Czesław. Katolicka akcja prasowo-kolportażowa. (Potrzeby, metody, środki), (Łódź: Biuro Ligi Katolickiej Diecezji Łódzkiej, 1930).

„Śmierć albo życie”, Niewiasta Katolicka, nr 10, 1931, 3.

Terpiłowska, Julia. „Sekcja Społeczno-Wychowawcza”, Rocznik Katolickiego Zwiazku Kobiet w Warszawie, 1911-1912, 10-12.

„Udział kobiet w XVIII sesji Ligi Narodów”, Kobieta Wielkopolska, nr 1, 1936, 4-5.

„Udział kobiet w życiu politycznym”, Kobieta Polska (krakowska), nr 12, 1918, 1.

Urban, Jan. „O prawa obywatelskie dla kobiet”, Przeglad Powszechny", t. 138-139, 1918, 276-293; t. 139-140, 414-431.

Wadowska, Helena, Ekielska, Maria. „O stanowisku kobiety”, Sodalis Marianum, nr 1, 1917, 12-19.

„Warto przeczytać”, Kobieta Polska (poznańska), nr 3, 1937, 12.

Wójcik, Stanisław. „O Katolicki Instytut Prasowy w Polsce”, Homo Dei, nr 6, 1936, 394-400.

„Z naszego ruchu”, Polka, nr 8, 1926, 4.

„Z ruchu w Stowarzyszeniach”, Kobieta Polska (krakowska), nr 4, 1920, 4-5. 
„Zagadnienie pracy kobiet na Międzynarodowej Konferencji Pracy”, Gazeta dla Kobiet, nr 9, 1930, 82.

Zaleska, Zofia. Czasopisma kobiece $w$ Polsce. (Materiały do historii czasopism). Rok 1818-1937, (Warszawa: Wyższa Szkoła Dziennikarska, 1938).

Zamoyska, Maria. Wspomnienia, (Kórnik: Fundacja Zakłady Kórnickie, 2017).

Zdanowska, Aniela. „Kursy dla kobiet”, Gazetka dla Kobiet, nr 6, 1924, 1-2.

„Zyski rozwódek”, Niewiasta Katolicka, nr 8, 1931, 3.

\section{Opracowania}

Chrapek, Jan, Góral, Jerzy. „Zarys ważniejszych wynalazków z dziedziny masowego komunikowania oraz wypowiedzi Kościoła na temat środków społecznego przekazu", w: Jan Chrapek (red.), Kościół a środki społecznego przekazu. Praca zbiorowa, (Warszawa: Pallotinum, 1990), 197-200.

Chwastyk-Kowalczyk, Jolanta. „Agitacja obywatelska przed- i powyborcza 1928 roku na łamach "Kobiety Współczesnej", Czasopismo Naukowe Instytutu Studiów Kobiecych, nr 1, 2019, 105-137.

Chwastyk-Kowalczyk, Jolanta. „Bluszcz” w latach 1918-1939. Tematyka społeczna oraz problemy kultury i literatury, (Kielce: Wydawnictwo Akademii Świętokrzyskiej, 2003).

Dajnowicz, Małgorzata, Miodowski, Adam (red.), Polityka i politycy $w$ prasie XX $i$ XXI wieku. Polityka $w$ prasie kobiecej, (Białystok: Wydawnictwo Uniwersytetu w Białymstoku, 2019).

Dufrat, Joanna. „Prasa politycznych organizacji kobiecych w Polsce w latach 1917-1939”, w: Małgorzata Dajnowicz, Adam Miodowski (red.), Polityka i politycy w prasie XX $i$ XXI wieku. Prasa organizacji politycznych, (Białystok: Wydawnictwo HUMANICA, 2017), 31-48.

Dziki, Sylwester. „Prasa wyznaniowa”, w: Walery Pisarek (red.), Słownik terminologii medialnej, (Kraków: Towarzystwo Autorów i Wydawców Prac Naukowych „Universitas”, 2006), 156.

Fikus, Feliks. „Wielkie wydawnictwo prasowe w małym mieście: dwie "Przyjaciółki"", Kwartalnik Historii Prasy Polskiej, nr 1, 1979, 79-93.

Grabowska, Joanna. „Moja Przyjaciótka”. Ilustrowany dwutygodnik kobiecy 1934-1939, (Żnin: Muzeum Ziemi Pałuckiej w Żninie, 1997). 
Kondracka, Mariola. Posłanki i senatorki II Rzeczypospolitej, (Warszawa: Wydawnictwo Sejmowe, 2017).

Krasińska, Izabela. „Niewiasta Polska“ (1899-1907) jako przykład pisma patronackiego - zarys monograficzny", Rocznik Biblioteki Naukowej PAU i PAN w Krakowie, R. LXII, 2017, 113-122.

Lechicki, Czesław. „Prasa katolicka Drugiej Rzeczypospolitej”, Kwartalnik Historii Prasy Polskiej, nr 2, 1984, 45-46.

Maj, Ewa. Dziennikarki prasy dla kobiet w Polsce 1918-1939. Portret zbiorowy na podstawie publicystycznego samopisu, (Lublin: Wydawnictwo Uniwersytetu Marii Curie-Skłodowskiej, 2020).

Maj, Ewa. „O pożytkach z badania prasy Narodowej Demokracji (do 1939 r.)", w: Agnieszka Łukasik-Turecka, Konrad Słowiński (red.), Logos $i$ ethos $w$ polityce. Ksiega jubileuszowa Profesora Stanisława Wójcika, (Lublin: Wydawnictwo Katolickiego Uniwersytetu Lubelskiego, 2020), 539-552.

Maj, Ewa. „Wzorzec kobiety w prasie dla katoliczek w Polsce międzywojennej: przypadek periodyku "Kuźniczanka" (1931-1936)", Czasopismo Naukowe Instytutu Studiów Kobiecych, nr 1, 2020, 113-139.

Michalska, Iwonna. „Rodzinne obowiazki kobiety w świetle katolickiego periodyku "Gazeta dla Kobiet" $z$ lat 1918-1938", Lubelski Rocznik Pedagogiczny, nr 1, 2020, 27-41.

Mirek, Małgorzata. „Wkład Amelii Starowieyskiej w rozwój czytelnictwa kobiet", w: Agnieszka Chamera-Nowak, Dariusz Jarosz (red.), Na co dzień $i$ od święta. Ksiażka $w$ życiu Polaków $w$ XIXXXI wieku, (Warszawa: Oficyna Wydawnicza Aspra-JR, 2015), 403-420.

Morawska, Joanna. „Wzorzec służącej propagowany na łamach katolickiego czasopisma "Przyjaciel Sług" na przełomie XIX i XX w.", Czasopismo Naukowe Instytutu Studiów Kobiecych, nr 2, 2017, 23-40.

Sołga, Przemysław. „Prasa jako czynnik kształtujący katolicką doktrynę medialna w XIX i XX wieku", Res Gestae. Czasopismo Historyczne, nr 3, 2016, 170-193.

Szlachta, Bogdan. „Action Française”, w: Michał Jaskólski (red.), Stownik historii doktryn politycznych, t. 1, (Warszawa: Wydawnictwo Sejmowe, 1997), 17-20.

Śliwa, Michał. „Udział kobiet w wyborach i ich działalność parlamentarna", w: Anna Żarnowska, Andrzej Szwarc (red.), Równe 
prawa i nierówne szanse: kobiety $w$ Polsce międzywojennej. Zbiór studiów, (Warszawa: Wydawnictwo DiG, 2000), 49-59.

Wodniak, Katarzyna. „Moja Przyjaciółka” 1934-1939. Przebój prasowy żninskich Zakładów Wydawniczych Alfreda Krzyckiego, (Żnin: Wydawnictwo Dominika Księskiego Wulkan, Bydgoszcz: Wydawnictwo Uniwersytetu Kazimierza Wielkiego, 2020). 